\title{
Reinterpretation of Amish Tripathi's Shiva Triology with Selected Verses of Bhagwat Gita
}

\author{
Rakhi Deshmukh ${ }^{1} \&$ Jaya Dwivedi ${ }^{2}$ \\ ${ }^{1}$ Assistant Professor, Swami Shri Swaroopanand Saraswati Mahavidyalya, Hudco Bhilai, \\ C.G, India and Research Scholar in the Department of English at N.I.T Raipur, C.G, India. \\ Email: rakhijayam@gmail.com. \\ ${ }^{2}$ Jaya Dwivedi is Assistant Professor in the Department of English at N.I.T, Raipur, C.G, \\ India.Email: jdwivedi.eng@nitrr.ac.in.
}

Received November 10, 2016; Revised December 15, 2016; Accepted December 20, 2016; Published January 14, 2017

\begin{abstract}
This paper explores the traits of leadership in Shiva Trilogy with special reference to Bhagwat Gita. A review of literature in this field shows that several studies have been done in the area of virtuous leadership development from various perspectives; however very few have been done to integrate the Bhagavad-Gita and any piece of literature like Shiva Trilogy by Amish Tripathi. As a result, this paper not only fills the gap in the literature of virtuous leadership development, but also provides some significance and insights on virtues and ethical development from the ancient Indian philosophical perspective. Unlike most of the outside-in western concepts unify with virtues, this research provides an inside-out approach to leadership where Shiva sets the traits of virtuous leader and Bhagwat Gita enlightens the path for achieving the same. If the virtues coupled with theoretical foundations are developed by present leaders it will enable them to define their leadership roles in a transformational manner with competence and wisdom, as Lord Shiva does in Shiva Trilogy.
\end{abstract}

Keywords: Shiva Trilogy, Bhagwat Gita, Amish Tripathi, Indian philosophy, leadership.

\section{Introduction}

The Bhagwad Gita can be referred to a body of literature in itself which almost every Hindu child has been socialized into whilst growing up (Swami, 2011). Gita has been taken up as a source of inspiration and guidance by the great leaders, intellectuals, scientist, philosophers and thinkers. Apart from constituting the bedrock of Hindu spiritual microcosm, the epic incurs a plethora of alternative uses as well. For instance if an in-depth reading of Bhagwad Gita is undertaken from the perspective of leadership a reader situated in the contemporary era will procure the needful understanding of what is implied by leadership as garnered with respect to the modern research and practice. Subsequently, it has been construed by Bhagwad Gita that the Leadership (Mahadevan, 2012) is in a paramount form solely when it helms an inspirational form. Inspirational leadership therefore undertakes several attributes which an individual lacks the clarity to coalesce in the present day times in conjunction with the leadership theories. In tandem with the domain of inspirational leadership, one of the paramount examples in the realm of the same is Shiva. Who is Shiva? One cannot conjure up to a prudent and an apt answer than Tripathi does in his debut novel, "Shiva! The Mahadev; The God of Gods, Destroyer of evil, passionate

(c) AesthetixMS 2016. This Open Access article is published under a Creative Commons Attribution Non-Commercial 4.0 International License (http://creativecommons.org/licenses/by-nc/4.o/), which permits non-commercial re-use, distribution, and reproduction in any medium, provided the original work is properly cited. For citation use the DOI. For commercial re-use, please contact editor@rupkatha.com. 
lover, fierce warrior, consummate dancer and the most important Charismatic leader".(Tripathi, 2011). As is widely known and accepted, Lord Shiva is also known as "The Transformer" and is a crucial and complex combination of a leader who is highly inspiring and motivating. The character of Shiva in the Trilogy has been adapted by Amish from Hindu mythology, narrating the tale of a man who rose to become God like in stature because of his "Karma", the Sanskrit term symbolic for Action. karma has been very adequately encapsulated in the Hindu mythological Epic literature, Bhagwat Gita with various verses as a true guide for developing the virtuous qualities in the leader. In this particular study the concept of Karma and Dharma of a leader has been given special attention specifically with pertinence to the consciousness of duty. Shiva Trilogy narrates journey of an extraordinary man who explores and channelizes his multitudes of energies in order to give a new meaning to the concept of philosophy, religion and karma (the action). As a normative statement, this research also argues that if leaders would adapt and learn the "lessons" provided by the Mythological drama, they will be able to perform their leadership roles virtuously.

According to Alexandre Havard (2007), "Leaders are not born, but trained. Why? Because virtue is a habit acquired through practice. Leadership is a question of character (virtue, freedom, self-improvement), not temperament (biology and genetics). Temperament may aid the development of some virtues and hinder others, but as and when the relevant virtues grow, they stamp character on our temperament so that temperament ceases to dominate us. Temperament is not an obstacle to leadership. The real obstacle is lack of character, which quickly leaves us drained of moral energy and quite incapable of leading"

Moreover, the character of Lord Shiva imbues moral energy as an instrument to overcome the obstacles that are associated with leadership. The Trilogy can be adjudged as the author's tribute to Shiva he is a devout Shiva follower. The author has taken the strands of myth, philosophy, and religion and also contemporises it with numerous guiding principles which can perhaps be adapted by the modern generations in order to turn into a virtuous leader and a better person. The trilogy under discussion pertains to decision making, problem solving and, and straitjacketing the relevant courses of action which constitute the most critical aspects of being a leader since it is risky and difficult. This study proposes to explore the numerous facets of the philosophical and mythological figures of Hinduism that could be ideally suited for the practices associated with leadership.

Amish Tripathi, the author of the iconic and adulated Trilogy has reportedly stated in one of the interviews that Lord Shiva is real and not certainly a myth, that most Gods of the polytheistic religion are a part of a pertinent question can be posed at this juncture, such as: Why are the myths of Hinduism alive in the contemporary times? A possible perspective to this statement can be the fact that the seemingly "age-old" myths are of poignant relevance in the contemporary times. Moreover, much to the Indian subcontinent's credit, it has produced a plethora of geniuses recurrently over the centuries, which have modernized and localized the Hindu myths ad nauseam. Change is then the parameter at stake in this particular regard, and parallels can be drawn with the election of Narendra Modi as the active Prime Minister of India, or subsequently the emergence of Aam Admi Party (a political party, chaired by Mr. Arvind Kejriwal) for a lot of Indian citizens is instrumental to the 'ray of hope' with respect to change. The battle cry of Trilogy is Har-Har Mahadev, was heard with lot of hullabaloo in the political gatherings of India's Prime Minister Mr. Narendra Modi. The premise of Trilogy is created among such political changes. Further the text of the Trilogy has been collated with the selective verses of Bhagwat Gita to make it normative analogy. Several researches (Macintyre, 1984; Solomon, 
1992; Goodpaster, 1991: Sinha \& Singh 2013,) have given emphasis to the myriad virtues of leadership and such virtues have been adhered by many leaders (Sinha \& Singh, 2013).

\section{Virtues of Leadership in Trilogy with selective verses of Bhagwat Gita}

Geeta has interesting reference to the virtues of leadership by the universally acclaimed and influential ideas of Bhagwat Gita regarding virtuous leadership and the Trilogy recounts the tale of the "savior" leader who is bestowed with the inimical potential to bring forth massive changes in the society. It would not be far-fetched to state that in the contemporary times, the Indian nation looks forward to the emergence of a leader who can work towards making the nation a "golden bird" in terms of restoring to it it's once coveted prosperity and peace which can probably be effectively attained by acting in accordance with "high" ethical and moral values. The idea of adhering to a Moral character has been portrayed by Tripathi as Shiva and the central and pivotal premises of the Trilogy supplemented with myriad guiding principles of Hindu mythology. Careful analysis of Trilogy gives the following virtues of leadership better supplemented with paradigm of Bhagwat Gita includes:

\section{Consciousness of Duty like Karma Yogis}

The philosophy of duty has been catered to in The Shiva Trilogy to set the yardstick for performing the requisite task with the efficiency and zeal of Karma Yogi. In this particular context, the character of Shiva in the due course of the progression of The Shiva Trilogy has set the yardstick of the incumbent consciousness of duty required in order to achieve the common goal of brotherhood for the society, (Meluha).The centrality of the tenet of the consciousness of duty in the doctrine of leadership has been duly exemplified in the first novel of the Shiva Trilogy especially in the following passage, wherein the author attempts to depict the heritage of Shiva's character effectively linking him to the Revered Hindu God, Shri Ramachandra,

"Lord Shiva to achieve the task of fulfilling the unfinished task of Lord Ram; "The simple truth hit Shiva: if the entire society was conscious of its duties, nobody would need to fight for their individual rights. Since everybody's right would automatically taken care of through someone else's duties. Lord Ram was a genius!"(Tripathi, Immortals of Melhua 35)

The centrality of consciousness of duty is also further exemplified in the subsequent passage which is a part of the narrative, "Consciousness of duty is an answer for any moral dilemma. "Only your karma is important. Not your birth. Not your sex. And certainly not the colour of your throat" (Tripathi, Immortals of Meluha). The particular notion of the leadership trait, which is the "concept" of duty and karma has been very adequately encapsulated in the Hindu mythological Epic literature, Bhagwat Gita in its Chapter 2 Verse 47: कर्मण्येवाधिकारस्तेमाफलेषुकदाचन।माकर्मफलहेतुर्भूर्मातेसङ्गोऽस्त्वकर्मणि॥, the aforementioned verse is implicative of the dogmatic truth that any existing being (in this context a Human being) has the right to work but not to its fruit. Let not the fruits of action be not your motive, nor let your attachment be inaction. It can be deduced from the textual interpretation of the Shiva Trilogy that when a leader performs like a Karma Yogi and duty becomes the part of his existence, then he never looks for any reason outside. At this juncture it would be apt to arrive at a somewhat rudimentary understanding of a Karma Yogi since this particular mythological category is analogically important to the present research. Karma Yogi is the one who performs his duty 
since it theoretically argues to perform duty. The pertinent importance of duty has been put in a nutshell in a beautiful fashion in chapter 3 verse 8 of the Indian mythological Epic, Bhagwat Geeta;नियतम्कुरुकर्मत्वंकर्मज्यायोहयोकर्मणःशरीरयात्रापिचतेनप्रसिद्धयेदकर्मणः it suggests that the existence of any human being is essentially rooted in performing his prescribed duties, as the adage goes on- "action is superior to inaction". Furthermore, it can be argued that even the physical existence of any human being cannot be maintained without the "performance" of action. Moreover, according to the numerous Hindu theological dogmas, performance of the prescribed activities is instrumental in achieving success and perfection, the desired goals in any society. In this context it can be asserted that Shiva's character in the Trilogy is intrinsically conscious of his duty to the extent that he feels that his duty towards humanity is more important and above anything. As the modern day leaders become susceptible to the aforementioned genre of performance inherently at most levels of their lives and careers, it becomes mandatory for the leaders to be conscious of their duties akin to Karma Yogis.

\section{Justice}

The philosophy of justice is adopted by Shiva's character to set the requisite standards as a part of Karma of the leader bringing together the individuals of a society under a system of justice. Numerous theories have been developed on justice by a multitude of ancient authors like Plato, Aristotle, Thomas and Hobbes. Philosophers have gone beyond this narrow meaning and have framed the concept of justice as a virtue of the character and a requisite quality of the political society and system entailed for ethical and social decisions. The idea of Justice mirrors the life of society and its people. This essential philosophy or Nirdeshika of Justice is followed by Lord Shiva's character in the Shiva Trilogy to achieve the task of universal brotherhood and RamRajya. Throughout the Trilogy the idea of justice is given unprecedented centrality over the "perfect life for its citizens" and this notion is encapsulated in an apt fashion in the succeeding passage wherein Lord Shiva is attempting to break or rupture an age old custom followed in Meluha in order to establish a sense of justice among their citizens., "If the purpose of justice is served by breaking a law, then break it.' 'Lord Ram said that?" (Tripathi, Immortals of Meluha 35) It can be argued that people of any nation are looking forward to such an aforementioned notion of justice which will attempt to break, rupture or mould the old or pre-existing laws or customs which are intrinsically creating a purposive restrain in the path of ethical progress of the society. Although a society cannot function without the existence and implementation of the requisite laws however when the idea of welfare of people is brought to the fore, change is essentially required. The pre-existing and obtuse laws have to be ruptured to form new and fair ones to purport a sense of justice and fairness in society or microscopically in any team. The way or path of achieving the virtue of justice has been described in a dense fashion in the chapter 18, verse 23 of the Hindu mythological epic literature, Bhagwat Geeta,; "नियतंस््गरहितमरागद्वेषत:कृतम् |अफलप्रेप्सुनाकर्मयतत्सात्विकमुच्यते || 23||" What is implicitly suggested through the aforementioned verse is that whenever an action is performed without attachment, without love or hate it becomes tainted with fairness and this fairness in decision making and performance brings forth a sense of justice for the team members of any organization in a psychological sense. On the flipside however, an action which is performed under the influence of any form of desire and a false notion of egoleads to passion. Furthermore, passion results in anger and the existence of anger results in inability to administer a just decision in a particular situation. Administering and implementing Justice which essentially is a desirable quality of a leader should be undertaken 
by the leader in order to bring forth progress and success in the ambit of the team of their respective organizations; as a team without the implementation of justice leads to the development of intolerance and conflict thereby rupturing the morale and team spirit of the incumbent members.

\section{The Third Eye}

According to a multitude of Hindu theological scriptures, the Third eye of Shiva is the symbol of power which is instrumental in the destruction of the requisite evils of society in general or a group in particular. The Third eye of Shiva's character in the Shiva Trilogy exists with him by birth and with respect to the question of its activation the solution is aptly recorded in the succeeding passage wherein the Vasudev chief, Gopal addresses a confused and a young Shiva's question 'Does this happen to others?' 'Yes, it does. But only amongst those who practice decades of yoga to train their third eye. (Tripathi, Oath of Vauputra 112)Analogically speaking with reference to the ethos of the present day body of Leadership the third eye can be achieved by the leaders by being focused, patient, and also by practicing the ancient Hindu cardiovascular exercise, Yoga in order to achieve a sense of control over the senses. Once a leader is able to master these definite virtues, he can undergo any complex situation and overcome the same with a sense of ease.

Role of Yoga practices which is also instrumental in bringing forth the presence of concentration has been summed up in the Hindu mythological literature, Bhagavad Geeta; particularly in its chapter 18, verse 33'धृत्याययाधारयतेमन:प्राणनन्द्रियक्रिया: योगेनाव्यभिचारिण्याधृति: सापार्थसात्विकी"||33| wherein the aforementioned verse indicates that unbreakable determination can be sustained by yoga practices and once the yoga practice becomes a part of the routine of an individual human being it enables them to control the mind which keeps on wavering in and out of tensions and pressures of job, thereby making life inimically difficult and devoid of peace. Yoga further enables to develop a notion of control over the senses. A plethora of noted practitioners of the ancient Hindu cardiovascular body exercise have empirically stated that cumulatively all the benefits derived from yoga are essentially amalgamated into the psychological mode of "goodness" alleviating the heart by eliminating the innate intrinsically negative psychological feelings of jealousy, odium , lust, rage, selfishness, smugness and egoism. On the flipside bestows the mind and being with the presence of positive psychological feelings of delight, divine ecstasy, harmony, calmness and knowledge. Turning to the dogma and practice of modern day leadership, this aforementioned genre of alleviation conspicuous by its presence in Yoga, is instrumental in taking the leader one notch further in his journey towards the journey of leadership enables him thereby with virtues to perform in a better fashion.

\section{Excess is denied}

The Gita comprises of a prudent sentence that encapsulates what the current research is attempting to convey: अतिसर्वत्रवर्जयेत्॥ "Which implies that excess in any manner whatsoever should be avoided; as excess of anything is bad. This quest of striving for a balance between the Good and the Bad is substantially put forth by the means of the succeeding passage, "Some of us are attracted to Good. But the universe tries to maintain balance. So what is good for some may end up being bad for others?"(Tripathi, Oath of the Vayuputra 59). With relevance to common parlance it can be stated that the excess of wealth, money, work, emotion, care, love, attachment, 
or any materialistic object in any form may create imbalance in the incumbent personality traits, interpersonal-intrapersonal skills and in the abilities of a leader. According to Aristotle, temperance, or balance, is a virtue. Imbalance out of excess in the virtues may affect the psychology of leader and the team resulting in poor relation with individuals and frustration among team members affecting quality, process and standard. Developing balance by avoiding excess may always be a virtue for an ideal leader.

\section{No Boast of Self}

'Oh' Neelkanth is the embodiment of that thought Maharishiji', said Bhagirath. 'He never calls himself the Mahadev. It is we who address him as such.' (Tripathi, Oath of Vauputra 172). Lord Shiva endowed with great qualities of a leader never made a boast of self before his team and people. This quality of Shiva makes him Mahadev, The Lord of Lords. Making a boast of self is a part of egotism. Egotism is the biggest enemy of individual or team. An egoist always make a false boast of self and his mind keeps on wavering to achieve materialistic comforts, as described in Geeta chapter 16 verse 15; इत्यज्ञानविमोहिता: || 15|| means such people remain in illusion by the egotism and live with ignorance. But a virtuous leader always keeps himself away from egotism like Lord Shiva. If a brilliant leader is not responsible he will be successful for a short period, but it will be difficult for him to maintain that success. Success is very personal and illusive. Success is different from happiness if an individual is successful but egoist he will never be happy. Character of Shiva urges us to leave the egotistic thought process for the ethical and moral advancement in life. No boast of self is the symbol of purity considered to be the best part of a leader because this purity of heart without boast of self encourages a wise leader to work for the welfare of team and society.

\section{Sheer personal bravery}

The most admirable quality of a leader is his personal bravery to face any situation. Bravery of the leader motivates for success, brings confidence in the team to achieve any goal. Sometime the lost war is won by the act of bravery. It motivates the peer group to perform outstanding. Virtuous leaders serve as potent role model to others it leaves a positive remark on the team. All the team members stay ready to help in any situation. This virtue of personal bravery of Shiva has been envisioned by the following impressions given by the members of His group that "All the Gunas spoke in one voice" "your decision is our decision" This respect for the chief was not just based on convention but also on Shiva's Characters. He had led the Gunas to their great military victories through his genius and sheer personal bravery. The virtue of bravery could bring more respect for the leader. This personal bravery has been emphasized in Geeta by describing the distinctiveness of a Khastriya and leaders in chapter 18 verse 43;शौर्यंतेजोधृतिर्दाक्ष्यंयुद्धेचाप्यपलायनम् । दानमीश्वरभावश्चक्षात्रंकर्मस्वभावजम् $\|$ 43\| this suggests the valor, strength, command, fortitude, ingenuity, courage in encounter, kindness, and leadership, these are the natural qualities of a leader. Their qualities were suitable for the belligerent and leadership. They formed the administrative class and lead the country. Still they did not consider themselves the supreme and they used to get advice on ideological, spiritual and policy matter from the Brahmins who were learned of spiritual and ethical dimension.Geeta suggests the bravery with ideological and ethical understanding. If the leaders develop this virtue of personal bravery with ethical and spiritual understanding they can perform far better and can lead the team with more wisdom. 


\section{Leading by Examples}

Leaders gain their reliability, esteem and authority from their staunch dedication to walking the talk. This is because; if the saying and doing of the leader is different no one will take him seriously or follow him. The behaviour and action of the follower are reciprocated by their observation. यद्यदाचरति श्रेष्ठस्तत्तदेवेतरो जनः। स यत्प्रमाणं कुरुते लोकस्तदनुवर्तते।|3.21|| Therefore it is mentioned in Gita that a leader needs to lead by setting example. As the actions and inactions are keenly observed by the followers and they follow the leaders. It is difficult to find such virtue in the leaders in modern time.Lord Shiva has set an example to lead the group, managing individual and achieving the goals. As it has been mentioned by one of the renowned Management expert John Adair as well. Shiva exudes an influencing personality juxtaposed with humble intensions reflecting His soft skills and input from the group to develop the team and the morale which can essentially be manifested through the trust and reliability placed on Shiva by his team members. Shiva's group Gunas rely on him intrinsically unanimously explicitly manifested in the passage of the novel where on the decision of Shiva all the Gunas spoke in one voice

"Your decision is our decision" You, on the other hand, are able to draw out the best in your followers, my friend. Don't think I did not understand what you did a few days back. You had decided upon your course of action already. But that did not stop you from having a discussion, allowing us to be a part of the decision." (Tripathi, Oath of Vauputra 168)

Such a spirit of team development wherein Shiva facilitated for all the members of his team an environment to discuss and to decide upon the course of action essentially becomes the key factor propelling team-work and cooperation. This essentially builds and boosts the morale and team spirit with feedback and input from the group.

Achievement of a goal or task predominantly depends on the leader and the constellation of a system act as an accolade which enable the leader to achieve requisite goal. If there is no presence of a great and virtuous leader, most of the goals cannot be realized. As Swami Vivekananda said "Religion is the constitutional necessity of mankind. Dharma is that which ultimately leads man to his real nature and the Supreme Goal". If Lord Shiva's character is taken within this particular context one can perhaps delineate an adequate justification of Shiva's organized planning with identifying aims of saving the life of numerous people and a pertinent visualization for the group to keep them together, moreover the notions of principle and pathdefines the action (the task) to yaks, men, and women, identifies resources in the strength of Yaks and Men, including the structure of three centric circle, which encapsulates the place of His people to save, and focus on time to attain the group goal of saving the life of his people in the form of three centric circles where people have been kept in the circles after proper planning and after identifying their capabilities and safety requirements. The composition of the composite circles are elucidated in an apt fashion in the following passages, "Expendable first, defenders second and the most vulnerable at the inside" (Tripathi, Immortals of Meluha7). Shiva in this context as a great leader was mentally prepared for the worst situation so he prepared such a strong defence mechanism with three circle layers. According to Adair "It is likely that the task will only be achieved if all members of the group work together towards the common good" (Harvey, T. 2009, Para 5) The group stands for a singular entity. In drawing parallels, it can be stated that the common good in the Trilogy has been taken as the philosophy of brotherhood. This is indicative of the fact that bringing the team together, managing the team as singular entity in leadership is the art of making the people contribute willingly and enthusiastically towards group goals, resolving group conflicts, developing team, morale and spirit. 
To manage the Individual members of a team they should not be treated as tailor-made tools to achieve the task assigned rather they should be treated in a respectful manner in an unbiased fashion identifying their qualities, strength, aims and fears. The accountable leader knows that the best friend, mentor, and adherent of a person is his own self. Self reliance is the way to success through self-belief. One has to develop through one's own hard work. No one else can develop any other one. An individual has to develop himself and other can lend a hand and contribute in that efforts. In the aforementioned context, it has been stated in Geeta that उद्धरेदात्मनात्मानं नात्मानमवसादयेत् |आत्मैव हयात्मनो बन्धुरात्मैव रिपुरात्मन: || 5|In congruence with the aforementioned theorist's argument, it can be analogically stated that insofar as Shiva is contextually considered as a virtuous leader, he is inimically capable of identifying, appreciating and straitjacketing the skills and potentials of his group members as a mentor and supporter. As a result of which, the constituent group members don't feel "dehumanized" or "atomized" since as a leader he doesn't consider them solely as a tool for achieving their tasks but is prudent in praising their individual skills which then reinforces their motivation and allegiance to fulfil the requisite tasks.

Shiva excelled in his Dharma of upholding the congregation of his army with unflattering commitment to the idea of saving the life of his people. It presents Shiva as role model maintaining coherence between his goals and his words with action. Such organized planning is a symbol of knowledge and wisdom of the leader. These circles accommodate all the qualities of a good planner and manager for achieving the task of defeating the opposition and saving the life of group.

\section{Conclusion}

The Hindu God, Lord Shiva has always been a source of moral energy and inspiration for devotees but it remained untouched by the researcher as a source of leadership traits with inside-out approach. This fictionalized contemporization of chronicles of Lord Shiva authored by Amish Tripathi, who holds a degree in management from Indian Institute of Management (IIM) Kolkata opens up an avenue to look into the insight of the soul of Lord Shiva for philosophies, spirituality, battles, mysteries and political commentary with messages for the world and a hope surges from Shiva himself. These iconic multitudes of possibilities can be reverberate in Bhagwat Gita by enlightening the path of achieving these virtues. Shiva becomes a strong role model for his followers by budding the moral standards and articulates powerful ideals throughout the Trilogy. As a leader by inculcating these traits of personality of Lord Shiva, a leader can attempt to overcome any difficult situation in an ethical way and these traits can be developed by following the path shown by of Bhagwat Gita provides strong theoretical and normative foundation for possible lessons of virtuous leadership.

\section{References}

1. Borker, Neha. 11 Lessons From Lord Shiva You Can Apply To Your Life. Accessed from http://www.indiatimes.com/culture/who-we-are/11-lessons-from-lord-shiva-you-can-apply-toyour-life-247674.html on May 18th 2016.

2. Chapman, A. (2000-2012). (John Adair Action-Centred Leadership Concept, review and summary.

Retrieved from www.businessballs.com 
3. Easwaran, Eknath. The Bhagavad Gita:(Classics of Indian Spirituality). Nilgiri Press, 2007.

4. Goyankada, J.: Shreemad Bhagwat Geeta: Tatvavivechani Hindi-Tika (Gorakhpur: Geeta Press)

5. Harvey, T. (2009). John Adair's Action Centred Leadership. Retrieved from www.learn-to-be-aleader.com

6. Havard, A. (2007).Virtuous Leadership, NewYork: Scepter Publishers

7. Krishnakuma, K. (Interviewer) \& Tripathi A. (Interviewee). (2011). Shiva in a New Light - An Interview with Amish Tripathi, Retrieved from http://www.sparkthemagazine.com/?p=2199

8. Mahadevan, B. "Leadership lessons from Bhagavad Gita." (2012): 13-16.

9. Muniapan, Balakrishnan, and Junaid M. Shaikh. "Lessons in corporate governance from Kautilya's Arthashastra in ancient India." World Review of Entrepreneurship, Management and Sustainable Development 3.1 (2007): 50-61.

10. Muniapan, Balakrishnan. "Kautilya's Arthashastra and perspectives on organizational management." Asian Social Science 4.1 (2007): 30.

11. Sinha, A.K \& Singh, S. (2014). "Virtues of Wise Leaders: Message from Bhagavad Gita", Purusharth Journal, Vol. VI, No. 2, 1.

12. Swami, His Divine Grace AC Bhaktivedanta. Bhagavad Gita as it is. The Bhaktivedanta book trust, 2011.

13. Tripathi, A. (2010). Immortals of Melhua, Westland: Print.

14. Tripathi, A. (2012). The Secrets of Nagas. Westland Ltd: Print.

15. Tripathi, A. (2013). The Oath of Vayuputras. Westland Ltd: Print.

16. https://ashokbhatia.wordpress.com/2013/07/12/management-lessons-from-mahabharata/

17. Natesan, Chinna N., Keefe, Michael J., and Darling, John, "Enhancement of Global Business Practices: Lessons from the Hindu Bhagavad Gita," European Business Review, 2009, Vol. 21, No.2.

18. Agarwal, Satya P., "The Social Message of the Gita: Symbolized as Lokasamgraha," Motilal Banarsidass, 1995. 